\title{
ANALISIS FAKTOR-FAKTOR PENENTU YANG MEMPENGARUHI JUMLAH PENDUDUK MISKIN REGIONAL DI INDONESIA
}

\author{
Unggúl Priyadi \\ Fakultas Ekonomi Universitas Islam Indonesia \\ priyadi.unggul@yahoo.com,883130101@uii.ac.id \\ Jati Asmoro \\ Fakultas Ekonomi Universitas Islam Indonesia
}

\begin{abstract}
This research investigate the socio-economic variables influencing the regional poverty in Indonesia. Using secondary data collected from the Central Bureau of Statistics, the independent variabels used in this reserach are regional income perkapita, income disparity, regional human development index and life expectation ratio. This research uses a pooled data analysis, i.e. random effect regression. The result of this research shows us that Human Development Index (HDI) and life expectation ratio are statistically effect the level of regional poverty in Indonesia.
\end{abstract}

Keywords: Poverty, pooled data, HDI, random effect

\section{PENDAHULUAN}

Kemiskinan merupakan masalah global, yang sering berkaitan dengan kebutuhan hidup, kesulitan hidup serta kekurangan di semua aspek kehidupan. Masalah kemiskinan memang telah lama ada sejak dahulu, di mana banyak negara yang sedang berkembang mengalami laju pertumbuhan ekonomi yang tinggi tetapi tidak membawa manfaat yang berguna bagi penduduknya. Ini dikarenakan tingkat kesenjangan yang terjadi juga semakin besar dan jumlah penduduk miskin tetap saja banyak. Indonesia juga mengalami masalah tersebut, dari sejak masa kemerdekaan hingga saat ini.

Penetapan penduduk miskin sesuai dengan yang ditetapkan dalam PP No. 42/1981, di mana orang, keluarga atau penduduk yang sama sekali tidak mempunyai sumber mata pencarian dan tidak mempunyai kemampuan untuk memenuhi kebutuhan hidup yang layak bagi orang atau keluarga dianggap miskin.

Menurut Badan Pusat Statistik, terdapat tiga golongan penduduk miskin yaitu (1) golongan miskin, dengan pendapatan per kapita per tahun beras antara $360-480 \mathrm{~kg}$, (2) golongan miskin sekali, dengan pendapatan per kapita per tahun beras sebanyak $240-360 \mathrm{~kg}$, dan (3) lapisan paling miskin, dengan pendapatan per kapita per tahun beras kurang dari 240 kg (Badan Pusat Statistik). 
Analisis Faktor-faktor Penentu ... (Unggul Priyadi dan Jati Asmoro)

Tabel Garis Kemiskinan, Jumlah dan Persentase Penduduk Miskin 1976-2009

\begin{tabular}{|c|c|c|c|c|c|c|c|c|}
\hline \multirow[t]{2}{*}{ Tahun } & \multicolumn{2}{|c|}{$\begin{array}{c}\text { Garis Kemiskinan } \\
\text { (rupiah) }\end{array}$} & \multicolumn{3}{|c|}{$\begin{array}{c}\text { Jumlah Penduduk Miskin } \\
\text { (juta) }\end{array}$} & \multicolumn{3}{|c|}{$\begin{array}{c}\text { Presentase Penduduk } \\
\text { Miskin } \\
\end{array}$} \\
\hline & Kota & Desa & Kota & Desa & $K+D$ & Kota & Desa & $K+D$ \\
\hline 1976 & 4552 & 2849 & 10.0 & 44.20 & 54.20 & $38 . \overline{80}$ & 40.40 & 40.10 \\
\hline 1978 & 4969 & 2981 & 8.30 & 38.90 & 47.20 & 30.80 & 33.40 & 33.30 \\
\hline 1980 & 6831 & 4449 & 9.50 & 32.80 & 42.30 & 29.00 & 28.40 & 28.60 \\
\hline 1981 & 9777 & 5877 & 9.30 & 31.30 & 40.60 & 28.10 & 26.50 & 26.90 \\
\hline 1984 & 13731 & 7746 & 9.30 & 25.70 & 35.00 & 23.10 & 21.20 & 21.60 \\
\hline 1987 & 17381 & 10294 & 9.70 & 20.30 & 30.00 & 20.10 & 16.10 & 17.40 \\
\hline 1990 & 20614 & 13295 & 9.40 & 17.80 & 27.20 & 16.80 & 14.30 & 15.10 \\
\hline 1993 & 27905 & 18244 & 8.70 & 17.20 & 25.90 & 13.40 & 13.80 & 13.70 \\
\hline 1996 & 38246 & 27413 & 7.20 & 15.30 & 22.50 & 9.70 & 12.30 & 11.30 \\
\hline 1996 & 42032 & 31366 & 9.42 & 24.59 & 34.01 & 13.39 & 19.78 & 17.47 \\
\hline 1998 & 96959 & 72780 & 17.60 & 31.90 & 49.50 & 21.92 & 25.72 & 24.23 \\
\hline 1999 & 92409 & 74272 & 15.64 & 32.33 & 47.97 & 19.41 & 26.03 & 23.43 \\
\hline 2000 & 91632 & 73648 & 12.30 & 26.40 & 38.70 & 14.60 & 22.38 & 19.14 \\
\hline 2001 & 100011 & 80382 & 8.60 & 29.30 & 37.90 & $9.7 \overline{6}$ & 24.84 & 18.41 \\
\hline 2002 & 130499 & 96512 & 13.30 & 25.10 & 38.40 & $14 . \overline{46}$ & 21.10 & 18.20 \\
\hline 2003 & 138803 & 105888 & 12.20 & 25.10 & 37.30 & 13.57 & 20.23 & 17.42 \\
\hline 2004 & 143455 & 108725 & 11.40 & 24.80 & 36.10 & 12.13 & 20.11 & 16.66 \\
\hline 2005 & 150799 & 177259 & 12.40 & 22.70 & 35.10 & 11.68 & 19.98 & 15.97 \\
\hline 2006 & 174290 & 130584 & 14.49 & 24.81 & 39.30 & 13.47 & 21.81 & 17.75 \\
\hline 2007 & 187942 & 146837 & 13.56 & 23.61 & 37.17 & 12.52 & 20.37 & 16.58 \\
\hline 2008 & $204 \overline{896}$ & 161831 & 12.77 & 22.19 & 34.96 & 11.65 & 18.93 & 15.42 \\
\hline 2009 & 222123 & 179835 & 11.91 & 20.62 & 32.53 & 10.72 & 17.35 & 14.15 \\
\hline
\end{tabular}

Sumber : Badan Pusat Statistik 2010

Berdasarkan tabel di atas jumlah penduduk miskin yang ada di Indonesia mengalami penurunan signifikan antara tahun 1976-1996 dari 54 juta jiwa turun menjadi 22,5 jiwa. Hal ini terjadi karena sampai tahun 1996, penentuan garis kemiskinan sebagai tolok ukur dalam menentukan jumlah penduduk yang miskin masih menggunakan standar yang lama sehingga belum dapat mencerminkan keadaan yang sebenarnya, terutama mengenai cakupan komoditi (Saleh, 2002).

Pada tahun 2003-2007 jumlah penduduk miskin mengalami fluktuasi pada kisaran 36-37 juta jiwa sedangkan pada tahun 2008-2009 jumlah penduduk miskin di Indonesia mengalami penurunan menjadi 32 juta jiwa. Hingga tahun 2009 jumlah penduduk miskin relatif cukup tinggi yaitu mencapai 14,15 persen. Hal tersebut menunjukan bahwa belum adanya kebijakan yang efektif yang dilakukan oleh pemerintah dalam mengurangi kemiskinan di Indonesia.

Sebelum dilakukan kebijakan untuk menanggulangi kemiskinan di Indonesia, seharusnya terlebih dahulu' pemerintah mengetahui faktor-faktor yang mempengaruhi kemiskinan yang terjadi selama ini, sehingga kebijakan yang dilakukan oleh pemerintah dalam mengurangi kemiskinan bisa berjalan efektif dan sesuai dengan sasaran atau tujuan selama ini.

Kemiskinan di suatu wilayah dipengaruhi dari beberapa aspek yaitu dari aspek kesehatan, modal manusianya (human capital) dan ketimpangan pendapatan. Dari aspek kesehatan itu sendiri dapat dilihat angka harapan hidup saat lahir adalah rata-rata tahun hidup yang akan dijalani oleh bayi yang baru lahir pada suatu tahun tertentu. Semakin tinggi angka harapan hidup di suatu wilayah, maka semakin baik pembangunan ekonomi di wilayah tersebut. Sedangkan 
dari segi modal manusia itu sendiri dapat dilihat dari kualitas manusia itu sendiri, semakin bagus kualitas manusia akan membuat kinerja ekonomi menjadi lebih baik dan sebaliknya.

Selama ini yang menjadi penghambat pertumbuhan ekonomi di suatu wilayah selain dari segi kesehatan maupun modal manusia adalah dari segi ketimpangan pendapatan. Ketimpangan pendapatan itu sendiri menyebabkan kesenjangan sosial semakin tinggi dan menyebabkan efisiensi ekonomi melemah.

Rendahnya pertumbuhan ekonomi dan jumlah penduduk yang besar akan berpengaruh terhadap kondisi sosial manusia di Indonesia. Pertumbuhan ekonomi merupakan kunci dari penurunan kemiskinan di suatu wilayah. Dengan pertumbuhan ekonomi yang meningkat di masing-masing provinsi mengindikasikan bahwa pemerintah mampu meningkatkan kesejahteraan masyarakatnya, sehingga dapat mengurangi tingkat kemiskinan.

Tujuan penelitian ini adalah menganalisis tingkat pendapatan per kapita per provinsi, human development index, ketimpagan pendapatan dan angka harapan hidup, mempengaruhi jumlah penduduk miskin. Kerangka konsep yang diacu untuk penelitian ini adalah: (1) Pendapatan Per Kapita, (2) Ketimpangan Pendapatan, dan (3) Human Development Index (HDI), dan (4) Kesehatan Berdasarkan Angka Harapan Hidup.

Pertama, Pendapatan Per Kapita atau dari Produk Domestik Regional Bruto (PDRB) menurut Badan Pusat Statistik (BPS) adalah jumlah nilai tambah yang dihasilkan oleh seluruh unit usaha dalam suatu wilayah, atau merupakan jumlah seluruh nilai barang dan jasa akhir yang dihasilkan oleh seluruh unit ekonomi di suatu wilayah. PDRB per kapita sendiri diperoleh dengan membagi PDRB dengan jumlah penduduk.

Pendapatan per kapita seringkali digunakan sebagai indikator pembangunan, karena pendapatan per kapita bisa memberikan gambaran tentang tingkat kesejahteraan. Semakin tinggi pendapatan seseorang maka akan semakin tinggi pula kemampuan seseorang untuk membayar (ablity to pay) berbagai pungutan yang ditetapkan pemerintah. Semakin tinggi PDRB per kapita suatu daerah, maka semakin besar pula potensi sumber penerimaan daerah tersebut.

Tingginya penerimaan daerah, diharapkan nantinya pemerintah daerah tersebut dapat mengatasi masalah kemiskinan daerahnya dengan baik (Arsyad,1999). Ini tentu berbeda seperti apa yang dinyatakan Todaro (1984). Dimana ia menyatakan pendapatan per kapita yang tinggi bukan merupakan jaminan tiadanya sejumlah kemiskinan absolut.

Kedua, ketimpangan pendapatan adalah suatu kondisi dimana distribusi pendapatan yang diterima masyarakat tidak merata. Ketimpangan pendapatan akan menyebabkan beberapa hal, antara lain inefisiensi ekonomi, melemahkan stabilitas sosial, solidaritas dan umumnya di anggap tidak adil (Todaro dan Smith, 2006). Ukuran yang biasa digunakan untuk merefleksikan ketimpangan pendapatan adalah salah satunya indeks gini (Gini Ratio)

Ketimpangan pendapatan dalam suatu negara akan meningkat pada tahap awal pertumbuhan ekonominya, kemudian pada tahap menengah cenderung tidak berubah dan akhirnyamenurun ketika negaratersebutsejahtera(Kuznets, Inverted U-curveHypothesis, 1955). Proses yang terjadi dalam hipotesis Kuznets tersebut akan dapat mengurangi kemiskinan karena pertumbuhan ekonomi yang tinggi dapat mengurangi jumlah penduduk miskin.

Dollar dan Kraay (2002) menentang teori Kuznets. Dimana, secara rata-rata, pendapatan kelompok termiskin dalam masyarakat akan meningkatsecara proporsional dengan peningkatan pendapatan rata-rata. Chen dan Ravallion (1997) menyatakan bahwa perubahan pendapatan dan perubahan ketimpangan tidak berkorelasi. 
Ketiga, Human 'Development Index (HDI). Menurut. Samsubar Saleh (2002), HDI merupakan salah satu faktor dari faktor-faktor penentu tingkat kemiskinan regional di Indonesia. $\mathrm{HDl}$ adalah pengukuran perbandingan dari harapan hidup, melek huruf, pendidikan dan standar hidup untuk semua negara seluruh dunia. HDI digunakan untuk mengukur keberhasilan atau kinerja (performance) suatu negara dalam bidang pembangunan manusia.

Indikator yang digunakan dalam HDI meliputi 3 dimensi dasar pembangunan manusia (Hakim, 2002):

1. Hidup yang sehat dan panjang umur yang diukur dengan harapan hidup saat kelahiran

2. Pengetahuan yang diukur dari angka buta aksara/tingkat baca tulis untuk orang dewasa dan dikombinasi dengan lama harapan sekolah

3. Standar kehidupan layak yang diukur melalui produk domestik bruto per kapita (GDP per kapita).

Nilai HDI suatu negara atau wilayah menunjukkan seberapa jauh negara atau wilayah itu telah mencapai sasaran yang ditentukan yaitu angka harapan hidup 85 tahun, pendidikan dasar bagi semua lapisan masyarakat (tanpa kecuali), dan tingkat pengeluaran dan konsumsi yang telah mencapai standar hidup yang layak. Semakin dekat nilai HDI suatu wilayah terhadap angka 100, semakin dekat jalan yang harus ditempuh untuk mencapai sasaran itu

Modal manusia (human capital) merupakan salah satu faktor penting dalam proses pertumbuhan ekonomi yang juga berpengaruh terhadap kemiskinan. Pembangunan modal manusia diyakini tidak hanya dapat meningkatkan produktivitas dan pertumbuhan, namun juga berperan sentral mempengaruhi distribusi pendapatan di suatu perekonomian. (Becker, 1964; Schultz, 1981 dalam Dian Satria, 2008).

Keempat, Kesehatan Berdasarkan Angka Harapan Hidup. Kesehatan merupakan salah satu faktor yang menyebabkan kemiskinan. Berbagai indikator kesehatan di negara-negara berpendapatan rendah dan menengah jika dibandingkan dengan negara-negara berpendapatan tinggi, memperlihatkan bahwa angka kesakitan dan kematian secara kuat berkorelasi (Laporan Komisi Makroekonomi dan Kesehatan, 2001).

Beberapa alasan meningkatnya beban penyakit pada penduduk miskin adalah:

1. Penduduk miskin lebih rentan terhadap penyakit karena terbatasnya akses terhadap air bersih dan sanitasi serta kecukupan gizi.

2. Penduduk miskin cenderung enggan mencari pengobatan walaupun sangat membutuhkan karena terdapatnya kesenjangan yang besar dengan petugas kesehatan, terbatasnya sumber daya untuk memenuhi kebutuhan dasar, dan terbatasnya pengetahuan untuk menghadapi serangan penyakit.

Kesehatan masyarakat di Indonesia biasanya ditunjukan dengan indikator berupa Angka Harapan Hidup (AHH). Dengan asumsi semakin panjang angka harapan hidup seseorang di suatu daerah maka menunjukkan adanya peningkatan kehidupan dan kesejahteraan bagi masyarakat di daerah tersebut. Peningkatan Angka Harapan Hidup di setiap tahunnya diharapkan akan meningkatkan kesejahteraan masyarakat. Dengan kesejahteraan yang semakin meningkat, maka tingkat kemiskinan diharapkan dapat berkurang.

Secara metodologis, teknik pengumpulan data dalam penelitian ini adalah pemanfaatan data-data sekunder, yang dihimpun oleh Badan Pusat Statistik Indonesia mulaj tahun 20072009. Data utama yang dianalisis adalah semua data variabel meliputi Jumlah dan Persentase Penduduk Miskin, PDRB Atas Dasar Harga Konstan 2000, HDI, Indeks Gini, dan Angka Harapan Hidup. Jenis data yang digunakan adalah data panel yaitu gabungan Time series 
dan Cross section. Data Time series dari tahun 2007-2009 dan obyeknya adalah 33 provinsi di negara Indonesia.

Untuk mengestimasi pengaruh PDRB per kapita, HDI, indeks gini, dan angka harapan hidup terhadap jumlah penduduk miskin digunakan alat analisis regresi dengan model data panel (pooled data). Ada 3 pendekatan yang digunakan dalam menganalisis panel data yaitu pendekatan Common Effects, Fixed Effects, dan Random Effects. Sebelum model di estimasi dengan model yang tepat, terlebih dulu dilakukan pemilihan model. Pemilihan model yang digunakan dalam sebuah penelitian perlu dilakukan berdasarkan pertimbangan statistik. Hal ini ditujukan untuk memperoleh dugaan yang efisien.

Penelitian ini ada dua uji yang dapat digunakan untuk memilih model yang terbaik. Pertama Uji F atau uji signifikasi Fixed Effects. Uji ini di lakukan untuk memilih yang terbaik antara model Common Effect (tanpa variabel dummy) atau dengan model Fixed Effect. Setelah melakukan estimasi data panel antara Common Effect dan Fixed Effect pemilihannya dilakukan dengan melihat nilai probabilitas $F$ statistiknya dengan hipotesis:

1. $\mathrm{H}_{0}$ : memilih menggunakan model estimasi Common Effect, jika nilai probabilitas F-statistiknya tidak signifikan pada $5 \%$.

2. $\mathrm{H}_{1}$ : memilih menggunakan model estimasi Fixed Effect, jika nilaj probabilitas F-statistiknya signifikan pada $5 \%$.

3. Dan yang kedua, Uji Hausman yaitu digunakan untuk memilih model yang antara estimasi Fixed Effect atau estimasi Random Effect, dengan uji hipotesis:

4. $\mathrm{H}_{0}$ : memilih menggunakan model estimasi Random Effect, jika nilai probabilitas F-statistiknya tidak signifikan pada $5 \%$.

5. $\mathrm{H}_{\mathbf{1}}$ : memilih menggunakan model estimasi Fixed Effect, jika nilai probabilitas F-statistiknya signifikan pada $5 \%$.

Model yang digunakan dalam penelitian ini adalah model cross-section yang dapat ditulis sebagai berikut:

$Y_{i}=\beta_{0}+\beta_{1} X_{i}+e_{i} ; i=1,2, \ldots, N$. Dimana $N$ adalah banyaknya data cross-section

Sedangkan persamaan model dengan time-series adalah :

$Y_{t}=\beta_{0}+\beta_{1} X_{t}+e_{t} ; t=1,2, \ldots, T$. Dimana $T$ adalah banyaknya data time-series

Mengingat data panel merupakan gabungan dari time-series dan cross-section, maka model dapat ditulis dengan :

$Y i_{t}=\beta_{0}+\beta_{1} X i_{t}+e_{i t}$

dimana :

$\mathrm{N} \quad=$ banyaknya observasi

$\mathrm{T} \quad=$ banyaknya waktu

$\mathrm{N} \times \mathrm{T}=$ banyaknya data panel

Dari persamaan di atas maka dapat di formulasikan model regresinya dalam bentuk log Iinier adalah sebagai berikut :

$\log P O V=\log \beta_{0}+\beta_{1} \log P D R B_{1 i t}+\beta_{2} \log R G_{2 i t}+\beta_{3} \operatorname{LogHDI}{ }_{3 i t}+\beta_{4} \log H H_{4 i t}+e_{i t}$

Keterangan :

$\log \mathrm{POV}_{\mathrm{it}} \quad=$ Jumlah penduduk miskin provinsi $\mathrm{i}$ tahun t (orang) 
$\log \beta_{0} \quad=$ Konstanta

$\beta_{1}, \beta_{2}, \beta_{3} . \quad=$ Koefisien variabel independent

$\log \mathrm{PDRB}_{1 \mathrm{it}}=$ Pendapatan per kapita per provinsi i tahun t (rupiah)

$\log R G_{2 i t} \quad=$ Kesenjangan pendapatan provinsi $i$ tahun $t$ (persen)

$\log \mathrm{HDI}_{3 i \mathrm{t}} \quad=$ Human Development Indeks provinsi $i$ tahun $t$

Log $\mathrm{HH}_{4 \mathrm{it}} \quad=$ Angka Harapan Hidup provinsi $\mathrm{i}$ tahun $\mathrm{t}$

\section{PEMBAHASAN}

Dalam mengestimasi apakah variabel yang digunakan berpengaruh terhadap jumlah penduduk miskin,-maka terlebih. dahulu dilakukan uji spesifikasi pemilihan model. Langkah pertama yang dilakukan, menggunakan uji F atau Uji Signifikansi Fixed effect yaitu membandingkan antara Common effets dengan Fixed effects. Hasilnya nilai distribusi statistik Chi Square dari perhitungan menggunakan E-views5 adalah sebesar 684.461682 dengan probabilitas 0.0000 (kurang dari $5 \%$ ), sehingga secara statistik $\mathrm{H}_{0}$ ditolak dan menerima $\mathrm{H}_{1}$, maka model yang tepat digunakan adalah model estimasi Fixed Effect.

Langkah berikutnya adalah uji Hausman, yaitu membandingkan antara Fixed effects dengan Random effects. Hasilnya nilai distribusi statistik Chi Square dari perhitungan menggunakan E-views5 adalah sebesar 5.373829 dengan probabilitas 0.2510 (lebih dari $5 \%$ ), sehingga secara statistik $H_{0}$ diterima dan menolak $H_{1}$, maka model yang tepat digunakan adalah model estimasi Random Effect.

Hasil estimasi model yang dipakai (Random Effects) persamaannya sebagai berikut: $\log P O V=21.84597-0.330501$ LogYPC -0.066330 LogRG - 14.13607 LogHDI + 9.776616 $\log \mathrm{HH}+\mathrm{e}$

Dari persamaan tersebut, menunjukkan bahwa jumlah penduduk miskin di Indonesia sebesar $21.84597 \%$ dengan asumsi tidak dipengaruhi variabel-variabel yang ada.

1. Jumlah penduduk miskin akan naik sebesar $0.330501 \%$, jika pendapatan per kapita (YPC) naik sebesar $1 \%$,

2. Jumlah penduduk miskin akan turun sebesar $0066330 \%$, jika ketimpangan pendapatan (RG) naik sebesar $1 \%$,

3. Jumlah penduduk miskin akan turun sebesar $14.13607 \%$, jika Human Development Index (HDI) naik sebesar $1 \%$,

4. Jumlah penduduk miskin akan naik sebesar $9.776616 \%$, jika angka harapan hidup $(\mathrm{HH})$ naik sebesar $1 \%$

Berdasarkan hasil estimasi Random Effect, diketahui bahwa variabel pendapatan per kapita (PDRB per kapita) tidak mempunyai pengaruh yang signifikan pada taraf nyata lima persen terhadap jumlah kemiskinan dengan nilai probabilitas ( $p$-value) 0.0742 dan memiliki kolerasi yang positif terhadap kemiskinan antar provinsi. Koefisien YPC yang diperoleh sebesar 0.330501 , artinya apabila pendapatan per kapita meningkat sebesar $1 \%$, maka jumlah penduduk miskin akan naik sebesar $0.330501 \%$. Hal tersebut tidak sesuai dengan hipotesis bahwa PDRB per kapita memiliki kolerasi negatif terhadap kemiskinan. Ini mengindikasikan bahwa kenaikan pendapatan per kapita belum tentu menurunkan tingkat kemiskinan. Hasil ini sesuai pendapat Todaro (1984) di mana pendapatan per kapita yang tinggi bukan merupakan jaminan tidak adanya kemiskinan absolut. 
Ketimpangan pendapatan (RG) tidak mempunyai pengaruh yang signifikan pada taraf nyata lima persen terhadap jumlah kemiskinan dengan nilai probabilitas ( $p$-value) 0.5717 dan memiliki kolerasi yang negatif terhadap kemiskinan antar provinsi. Koefisien RG yang diperoleh sebesar -0.066330 , artinya apabila ketimpangan pendapatan turun sebesar $1 \%$, maka jumlah penduduk miskin akan turun sebesar $0.066330 \%$. Hal tersebut sesuai dengan hipotesis bahwa RG memiliki kolerasi negatif terhadap kemiskinan.

Dari analisis diindikasikan bahwa ketimpangan pendapatan tidak berkolerasi atau berhubungan dengan kemiskinan. Analisis tersebut sesuai dengan pendapat Field (1989) yang menyatakan tidak ada hubungan sistematis antara ketimpangan pendapatan dan tingkat pertumbuhan ekonomi. Ini diperkuat dengan pendapat Dollar dan Kraay (2002) yang menyatakan bahwa secara rata-rata, pendapatan kelompok termiskin dalam masyarakat akan meningkat secara proporsional dengan peningkatan pendapatan rata-rata. Chen dan Ravallion (1997) juga menyatakan bahwa perubahan pendapatan dan perubahan ketimpangan tidak berkorelasi.

Human Development Index (HDI) berpengaruh signifikan pada taraf nyata lima persen terhadap jumlah kemiskinan dengan nilai probabilitas ( $p$-value) 0.0000 dan memiliki kolerasi yang negatif terhadap kemiskinan antar propinsi. Koefisien HDI yang diperoleh sebesar -14.13607 , artinya apabila HDI turun sebesar $1 \%$, maka jumlah penduduk miskin akan naik sebesar $14.13607 \%$. Hal tersebut sesuai dengan hipotesis bahwa HDI memiliki kolerasi negatif terhadap kemiskinan.

Dari analisis diindikasikan bahwa jika semakin banyak human capital maka akan dapat mengurangi pengangguran, menambah tenaga kerja ahli dan dapat meningkatkan upah yang tinggi sehingga dapat mengurangi jumlah kemiskinan. Hal ini juga diperkuat dengan hipotesis trickle down yang berpendapat bahwa pertumbuhan ekonomi yang cepat akan memberi sumbangan pada pembangunan manusia. Jika pembangunan membesar, maka masyarakat dapat membelanjakan lebih banyak untuk pembangunan manusia.

Menurut Kuznets yaitu dimana pertumbuhan ekonomi sebagai kemampuan jangka panjang untuk menyediakan berbagai jenis barang ekonomi yang terus meningkat kepada masyarakat. Kemampuan ini tumbuh atas dasar kemajuan tekhnologi, institusional dan ideologis yang diperlukannya. Sesuai dengan apa yang dinyatakan (Becker, 1964; Schultz, 1981 dalam Dian Satria, 2008) bahwa pembangunan modal manusia diyakini tidak hanya dapat meningkatkan produktivitas dan pertumbuhan, namun juga berperan sentral mempengaruhi distribusi pendapatan di suatu perekonomian.

Angka Harapan Hidup $(\mathrm{HH})$ berpengaruh signifikan pada taraf nyata lima persen terhadap jumlah kemiskinan dengan nilai probabilitas ( $p$-value) 0.0230 dan memiliki kolerasi yang positif terhadap kemiskinan antar propinsi. Koefisien angka harapan hidup yang diperoleh sebesar 9.776616, artinya apabila angka harapan hidup naik sebesar $1 \%$, maka jumlah penduduk miskin akan naik sebesar $9.776616 \%$. Hal tersebut tidak sesuai dengan hipotesis bahwa $\mathrm{HH}$ memiliki kolerasi negatif terhadap kemiskinan. Ini menunjukan semakin tinggi angka harapan hidup akan menambah banyak juga jumlah penduduk miskin.

\section{PENUTUP}

Pendapatan per kapita mempunyai pengaruh positif dan tidak signifikan mempengaruhi kemiskinan. Hal ini dikarenakan bahwa peningkatan PDRB tidak selalu diikuti oleh penurunan kemiskinan, dari data PDRB dan data kemiskinan di Indonesia tahun 2007-2009. Ini juga berarti kenaikan pendapatan per kapita belum tentu menurunkan tingkat kemiskinan. Ketimpangan pendapatan $(R G)$ tidak mempunyai pengaruh yang signifikan dan memiliki kolerasi yang 
negatif terhadap kemiskinan antar provinsi.: Koefisien'RG yang diperoleh sebesar -0.066330 , artinya apabila ketimpangan pendapatan turun sebesar $1 \%$, maka jumlah kemiskinan akan naik sebesar 0:06\%.

Human Development Index berpengaruh signifikan dan memiliki kolerasi yang negatif terhadap kemiskinan antar propinsi. Koefisien HDI yang diperoleh sebesar -14.13607 , artinya apabila HDI turun sebesar $1 \%$, maka jumlah kemiskinan akan naik sebesar $14.1 \%$. Angka Harapan Hidup berpengaruh signifikan dan memiliki kolerasi yang positif terhadap kemiskinan antar propinsi. Koefisien angka harapan hidup yang diperoleh sebesar 9.776616, artinya apabila angka harapan hidup naik sebesar $1 \%$, maka jumlah kemiskinan akan naik sebesar $9.77 \%$.

Kemiskinan lebih banyak dipengaruhi oleh $\mathrm{HDI}$ dan angka harapan hidup di bandingkán pendapatan per kapita dan ketimpangan pendapatan. Ini berarti kemiskinan di Indonesia tidak terpengaruh dengan besarnya pendapatan per kapita yang dapat menimbulkan kesenjangan pendapatan. Pemerintah diharapkan mampu meningkatkan total produksi barang dan jasa yang dihasilkan di seluruh Provinsi yang ada di Indonesia supaya peningkatan PDRB dapat mempengaruhi kemiskinan secara signifikan. Pemerintah juga perlu meningkatkan Angka Harapan Hidup dan human capital agar kualitas kesehatan penduduk dan SDM terus meningkat. Hal ini akan menunjang produktivitas penduduk, sehingga pendapatan yang diperoleh lebih maksimal dan kemiskinan akan berkurang.

\section{DAFTAR PUSTAKA}

AditAgus Prastyo (2010). "Analisis Faktor-faktor yang Mempengaruhi Tingkat Kemiskinan (Studi Kasus 35 Kabupaten di Jawa Tengah)", Skripsi Sarjana, Fakultas Ekonomi Universitas Diponegoro Semarang.

Widiastuti, Ari (2010). "Analisis Faktor-faktor yang Mempengaruhi Kemiskinan di Jawa Tengah Tahun 2004-2008", Skripsi Sarjana, Fakultas Ekonomi Universitas Diponegoro Semarang.

Badan Pusat Statistik (2009). Indonesia Dalam Angka 2009. Jakarta: BPS.

(2007). Data dan Informasi Kemiskinan 2007. Jakarta: BPS.

(2009). Indikator Kesejahteraan Rakyat, 2009. Jakarta: BPS.

(2009). PDRB Indonesia 2009. Jakarta: BPS.

(2009). Angka Harapan Hidup. Jakarta: BPS.

Hudaya, Dadan (2009). "Faktor-faktor yang Mempengaruhi Tingkat Kemiskinan di Indonesia", Skripsi Sarjana, Fakultas Ekonomi dan Manajemen, Institut Pertanian Bogor.

Hakim, Abdul (2002). "Ekonomi Pembangunan", Jurnal Ekonisia Fakultas Ekonomi Universitas Islam Indonesia, Yogyakarta.

Siahaan, Harlem (1995). "Kemiskinan dan Pertumbuhan Ekonomi", dalam Majalah berkala Prisma. 
UNISIA, Vol. XXXIII No. 75 Juli 2011

Kuncoro, Mudrajat (2006). Ekonomika Pembangunan. Yogyakarta: UPP STIM YKPN

Wijayanto, Ravi Swi ( ). "Analisis Pengaruh Pdrb, Pendidikan Dan Pengangguran Terhadap Kemiskinan Di Kabupaten / Kota Jawa Tengah Tahun 2005-2008" Skripsi Sarjana, Fakultas Ekonomi Universitas Diponegoro Semarang.

Saleh, Samsubar (2002) "Faktor-faktor penentu tingkat kemiskinan regional di Indonesia", dalam Jurnal Ekonomi Pembangunan vol 7, no 2, hal 87-102, Fakultas Ekonomi Indonesia, Universitas Islam Indonesia.

Soekanto, Soerjono (1982). Sosiologi, Suatu Pengantar, Jakarta: Rajawali Pers.

Sukirno, Sadono (2004). Makro Ekonomi, Teori Pengantar, Rajawali Pers, Jakarta

Todaro, Michael P. (1984). Ekonomi Bagi Negara Sedang Berkembang. Jakarta: Akademika Pressindo.

Widarjono, Agus (2007). "Ekonometrika Teori dan Aplikasi", Jurnal Ekonisia, Kampus Fakultas Ekonomi Universitas Islam Indonesia, Yogyakarta

http://sukabumikab.bps.go.id/component/content/article/69-sosial/152-gini-ratio.html http://djorky112.blogspot.com/2010/02/gini-ratio-indonesia.html http://engkyblog.blogspot.com/2011/02/kritik-teori-kemiskinan-dan-indeks.html http://blog.uin-malang.ac.id/nita/2011/01/06/kemiskinan-dan-kesenjangan-pendapatan/ http://rohilkab.bps.go.id/content/sekilas-tentang-angka-kemiskinan http://regional.kompas.comread2009033120514849 http://www.kabarbisnis.com/aneka-bisnis/2818971 kemiskinan.html

Transmigrasi_solusi_pengurangan_ 